\title{
Identifying Temporal Expression and its Syntactic Role Using FST and Lexical Data from Corpus
}

\author{
Juntae Yoon \\ jtyoon@daumcorp.com \\ Daum Communications Corp. \\ Kangnam-gu, Samsung-dong, 154-8 \\ Scoul 135-090, Korea
}

\author{
Yoonkwan Kim Mansuk Song \\ \{general,mssong\}@december.yonsei.ac.kr \\ Dept. of Computer Science, Engincering College \\ Yonsei Univ. \\ Seoul 120-749, Korea
}

\begin{abstract}
Accurate analysis of the temporal expression is crucial for Korean text processing applications such as information cxtraction and chunking for efficient syntactic analysis. It is a complicated problem since temporal expressions often have the ambiguity of syntactic roles. This paper discusses two problems: (1) reprosenting and identifying the tomporal expression (2) distinguishing the syntactic function of tho temporal expression in case it has a dual syntactic role. In this paper, temporal expressions and the context for disambiguation which is called local context are represented using lexical data cxtracted from corpus and the finite state transducer. By $\mathrm{ex}-$ periments, it turns out that the method is eflective for temporal expression analysis. In particular, our approach shows the corpus-based work could make a promising result for the problem in a restricted domain in that we can eflectievely deal with a large size of loxical data.
\end{abstract}

\section{Introduction}

Accurate analysis of the temporal expression is crucial for text processing applications such as information extraction and for chunking for officient syntactic analysis. In information extraction, a user might want to get a piece of information about an cvent. Typically, the event is related with date or time, which is represented by temporal expression.

Chunking is helpful for efficient syntactic analysis by removing irrelevant intermediate constituents gencrated through parsing. It involves tho task to divide sentences into non-overlapping segments. As a result of chunking, parsing would be a problem of analysis inside chunks and between chunks (Yoon, et, al., 1999). Chunking prevents the parser fiom producing intermediate structures irrelevant to a final output, which makes the parser efficient without losing accuracy. Thus, it turns ont that chunking is an esscntial stage for the application system like MT that should pursue both efficiency and precision.

Korean, an agglutinative language, has welldeveloped functional words such as postposition and ending by which the grammatical function of a phrase is decisively determined. Besides, because it is a head final language and so the head always follows its complement, the chunking is relatively casy. However, we are also faced with an ambiguity problem in chunking, which is often due to the temporal expression. This is because many temporal nouns are used as the modifier of noun and verb in a sentence. Let us consider the following examples:

\section{[Example]}

la jinan(last) yeoreum(summer) uri-neun (we/NOM) hamgge (together) $\operatorname{san-e(to)~moun-}$ tain) gassda(went)

$\rightarrow$ We went to the mountain together last summor.

1b jinan(last) yeoreum(summer) banghag-e(in va cation) uri-neun(wo/NOM) hamgge(together) san-e(to mountain) gassda(went)

$\rightarrow$ We went to the mountain together in the last, summer vacation.

2a 10 weol(October) $9 \mathrm{il}(9 \mathrm{th})$ jeonyeog(evening) 7 si(7 o'clock) daetongryeong-yi (president/GEN) damhwa-ga(talk/NOM) issda(bo)

$\rightarrow$ The prosident will give a talk at $7: 00 \mathrm{pm}$ in Oct. 7 th.

2b 10 weol(October) 9 il( 9 th) jeonyeog(evening) 7 si(7 o'clock) bihaenggipyo-reul(flight ticket/ ACC) yeyaghal su issseubnigga(can reserve)

$\rightarrow$ Can I reserve the flight ticket for $7: 00 \mathrm{pm}$ in Oct. 7 ?

In the examples, cach temporal expression plays a syntactically different role used as noun phrase or adverbial phrase (The underlined is a phrase) although they comprise the same phrasal forms. The temporal expressions in $1 \mathrm{a}$ and $2 \mathrm{a}$ of the cxample serve as the temporal adverb to modify predicates. On the other hand, the temporal expressions in 1 b and $2 \mathrm{~b}$ are used as the modifier of other nouns. That, is, as a temporal noun cither contributes to construction of a noun compound or modifies a predicate, it causes a structural ambiguity.

One solution might be that the POS tagger assigns a different tag to cach temporal noun e.g. NN 
and $A D V$. Howerer, since dependencies of temponal nouns are lexically decided, it does not seem that their syntactic tags could bo accurately predicted with a relatively small size of POS tagger corpus. Also, the simple rule based approach camnot make satisfactory results without lexical information. As such, identification of temporal expression is a conplicated problem in Korean text analysis.

'This paper discusses identification of temporal expressions and their syntactic roles. In this paper, we would deal with two problems: (1) representing and identifying the temporal exporession (2) distinguishing its syntactic function in case it, las a dual syntactic role. Actually, the two poblems are closely related since the identification and disambiguation process would be done under the representiation scheme of temporal expression. The process bases on lexical data extracted from corpus and the finite state transducer (I'S'I'). According to on obscrvation of texts, wo could soe that a fow words following a temposal nom have great effect on the syntactic function of the temporal nomn. Therefore, we note that the stiuctural ambiguity could bo rosolved in local contexts, and so obtain lexical information for the local contexts from corpus. The lexical data which contain contexts for clisambignation are represented with temponal word transition over the FST:

Briefly describing our mothodology, we first oxtract concordance data of cach temporal word using a. concosdance peogram. The co-occurences depresent relations between temporal words and also oxplain how temporal nowns and common notus are combined to genorate a compound nomu. It would be the likelihood of word combination, which helps disambiguate the syntactic role if a temponal word liave a syntactic cluality. In particular, we classify tomporal nonns into 26 classes in accordance with their meaning and function. Thus, the word cooccurrences become those annong temporal elasses or temporal classes and other nouns, which results in reducing the parameter space. Second, temporal expressions containing the co-occunences of temporal classes and other nouns are represented with the FST to identify temporal expressions and assign thoir syntactic tags in a sentenco. It has boen shown that the FST presents a very eflicient way for representing phrases with locality. 'The input of the l'S'I' is the result from morphological analysis and POS tagging (here, the temporal nom is tagged only as noun). Its ontput is the syntactic tag for each word in the sentence and temporal words are attached tags such as noun and alverl. Figure 1 shows the overall systom from the mophological analyzer to the chumiker.

Therefore, the process attaches syntactic labels to the previons examples so that chunking would be safely executed from the results as follows:

[Example]

la' $[\text { jinan(last) yeoreum(summer) }]_{T A}$ uri-neun (we/NOM) hamgge(together) san-e(to mountain) gassda(wont)

$\rightarrow$ We went to the mountain together last sumnor.

$1 b^{\prime}[\text { jinan(last) yeorcum(summer) }]_{T^{\prime} N^{\prime}}$ banghage(in vacation) uri-neun(we/NOM) hamgge (together) san-e(to mountain) gassda(went)

$\rightarrow$ We went to the mountain together in the last summer vacation.

$2 \mathrm{a}^{\prime}[10$ weol(()ctober) $9 \mathrm{il}(9 \mathrm{th})$ joonyeog(evening) 7 si(7 o'clock)] $]_{1}$ d daetongrycong-yi (president/GEN) damhwa-ga(talk/NOM) issda(be)

$\rightarrow$ The president will give a tialk at $7:(00)$ pm in oct. 7th.

$2)^{\prime}[10$ weol(October) 9 il(9th) joonyeog(evening) $7 \quad$ si(7 o'clock $)]_{T N}$ bihacnggipyo-reul(flight ticket/ACC) yeyaghal su issseubnigga(can reserve)

$\rightarrow$ Can I reserve the flight ticket for $7:(00)$ m in ()ct. 7?

\section{Related Works}

Abnoy (1991) has proposed text chunling as a preliminary step to parsing on the basis of psychological evidence. In his work, tho chunk was defined as a partitioned segment which corresponds in somo way to prosodic patterns. In addition, commplex attachment decisions as ocemring in NP or Vl' analysis are postponed without being decided in chunking. Ramshaw and Mareus (1995) introduced a baseNP which is a 110n-1ecursive NP. 'They used tansformation-based learning to identify nonrecursive basoNPs in a sentence. Also, V-type chunk was introduced in their system, and so they tried to partition sentences into non-overlapping $N$-type and V-type chunlis. Yoon, ot al. (1999) hare definced chunking in various ways for officiont analysis of Koroan texts and shown that the method is very effective for practical application.

l3esicles, there have been many works based on the finite state machine. 'I'he finite state machine is often used for systems such as speech processing, pattern matching, POS tagging and so forth because of its efficiency of speed and space and its convenience of representation. As for parsing, it is not, suitable for full parsing based on the grammar that, has recurrent property, but for partial parsing requiring simple state transition. Roche and Schabes (1995) have transformed the Brill's rule based tagger to the optimized deterministic FST and inproved the specd and space of the tagger. 4 notable one rebated to this work is about local grammar presented in Gross (1993), which is suitable for representing 
sentence

jinan yeoreum banghag-e uri-neun hamgge san-e gassda

11

Morp Anal and POS Tagger

11

jinan/A yeoreum/N banghag/N-c/l' uri/PN-neun/P hamgge/AD san/N-c/P ga/V-ss/TE-da/E

11

FST for idetilying temporal expression

11

jinan/A_tn ycorcum/N_tn banghag/N-c/I'uri/PN-neun/P hamgge/AD san/N-c/P ga/V-ss/TE-da/l:

11

Texı Chunker

11

[jinan/A_tn ycorem/N_tn banghag/N-e/P] [uri/PN-neun/P] [hamgge/AI)] [san/N-e/P] [ga/V-ss/TE-da/E]

Figure 1: System overview from the morphological analyzer from the chunker

rigid phrases, collocations and idioms unlike global grammar for describing sentences of a language in a formal level. The temporal expression was reprosented with local grammar in his work, where it was claimed that the formalism of finite automata could be easily used to represent them.

\section{Acquiring Co-occurrence of Temporal Expression}

\subsection{Categorizing Temporal Nouns}

Since many words have in common a similar: meaning and function, they can be categorized by their features. So do temporal nouns. That is, we say that 'Sunday' and 'Monday' have the same features and so would take the similar bchavior patterns such as co-occurring with the similar words in a sentence or phrase. Hence, in the first place we categorize temporal nouns according to their meaning and function. We first select 259 temporal nouns and divide them into 26 classes as shown in Table 1. Among them, some temporal words have syntactic duality and others play one syntactic role. Thus, the disambiguation process would be applied only to the words with dual syntactic functions.

\subsection{Acquisition of Temporal Expressions from Corpus}

Temporal words would be combined with each other in order to be made reference to time, which is called temporal expression. Since a temporal expression is typically composed of onc or a few temporal words, it secms to be possible to describe a grammar of

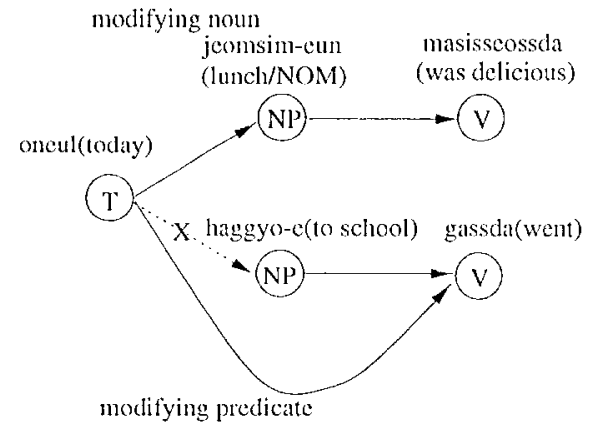

Figure 2: Syntactic functional ambiguity of temporal expression

the temporal expression with a simple modol like finite automata. In the practical system, however, we are confronted with a complicated problem in trcating temporal expressions since many temporal words have a functional ambiguity used as both a nominal and predicate modifier. For instance, a temporal noun oneul(today) could play a differont role in the similar situation as shown in Figure 2. In the first and the second path, the words to follow oneul are all noun, but the roles (dependency relations) of oncul are different.

Accurate classification of thcir syntactic functions is crucial for the application system since great difference would be made according to accuracy of the dependency result. Practically, we therefore should take into consideration the structural ambiguity resolution as well as their representation itsolf in identi- 


\begin{tabular}{|c|c|c|c|c|}
\hline \multicolumn{3}{|c|}{ word category } & class \# & temporal words \\
\hline \multirow{2}{*}{ temporal prefixes } & \multicolumn{2}{|c|}{ modifier } & 1 & ol(this $),$ jinan(last $), \ldots$ \\
\hline & \multicolumn{2}{|c|}{ number } & 2 & number ... \\
\hline \multirow{13}{*}{ tomporal nouns } & \multicolumn{2}{|c|}{ temporal nnit } & $3-10$ & segi (centry), nyeon(yoar), \\
\hline & \multicolumn{2}{|c|}{ crat, age } & 11 & gosaengdae(Paleoroic), \\
\hline & \multicolumn{2}{|l|}{ years } & 12 & geumnyeon(this year), saehac(new year), ... \\
\hline & \multicolumn{2}{|c|}{ months } & 13 & nacdal(next month), jeonguol(January), ... \\
\hline & \multicolumn{2}{|c|}{ wecks } & 14 & geumju(this weck), nueju(next weck), ... \\
\hline & \multirow{3}{*}{ days } & day of week & 15 & ilyo'il(Sunday), wolyo $i l, \ldots$ \\
\hline & & dayl & $16-17$ & haru(one day), chuseog(Thanksgiving day), .. \\
\hline & & day 2 & 18 & oneul(today), nac'il(tomorrow $), \ldots$ \\
\hline & \multirow{5}{*}{$\begin{array}{l}\text { time } \\
\text { and } \\
\text { dura- } \\
\text { tion }\end{array}$} & tinncl & 19 & sacbycog(dawn), achim(morning), ... \\
\hline & & time2 & $20-21$ & yeonmal(yoar-cond), ... \\
\hline & & scasoll & 22 & bom(spring), yeoreum(summer), .. \\
\hline & & specific duration & 23 & hwanjoolgi(time of season changing), $\ldots$ \\
\hline & & edge & $24-25$ & chogh(early time), junglan(mid), ... \\
\hline temporal suffixes & \multicolumn{2}{|c|}{ temporal suffixes } & 26 & dongan(during), naenoe(through), \\
\hline
\end{tabular}

Table 1: Categorization of temporal words

fying temporal expressions. The point that we note here is that, wo could predict the syntactic function of tempomal words by looking alicad one or two words. Namely, looking at a few words that follows a temporal word we can figure out which word the temporal expression modifics, and call the following words local context.

Unfortunately, it is not easy to define the local context for determining the syntactic function of each temporal word because they are lexically related. That is, it is wholly diflerent from each word whether a temporal nom would modify other nom to form a componnd nom or morlify a predicate as au aclverbial phrase. Otu approach is to use corpus to accuire information about the local context. Since we could obtain from corpus as many examples as noeded, rules for compound word gencration an be constructed from the examples. In this paper, we use co-ocenrence relations of temporal nouns extracted from large corpus to represent and construct rules for identification of temporal expressions.

As mentioned before, we wonld pay attention to two points here: (1) In what order a temporal expression would be represented with temporal words, i.c. description of the temporal expression network. (2) how the local context would be described to resolve the ambiguity of the syntactic function of temporal expressions. For this purpose, we first cxtract example sentences containing cach of 259 temporal words from corpus using the KAIST concordance progran' (KAIS'T, 1998). 'The number of temporal words is small and so we could manually manipulate lexical datia extracted from corpus. Figure 3

\footnotetext{
${ }^{1}$ KAIST' corpus consists of about 50 million cojeols. Lojeol is a spacing unit composed of a content word and functional words.
}

shows example sentences about yeoreum(summor) extracted by the concordance program.

Second, wo solect only the phrases related with temporal words from the examples (Table 4). As shown in Table 4, yeoreum is associated with varying words. 'Iemponal words like temporal profixes can come before it and common nouns can follow it. In this stage we describe contexts of each tomporal word and the ontput (syntactic tagk of the temponal word) under the given context. In particular, each temporal word is assigned a temporal class. Bosides, other nouns serve as local contexts for disambigualtion of syntactic function of temporal words.

From tho examples, wo can see that if bam(night), bycoljang(villa), banghag(vacation) and so on follows it, yeoreum serves as a component of a componnd noun with the following word. On the other hand, the word nacnae which means all the time is a temporal noun and forms a temporal adverlial phrase with other preceding temporal noun. Moreover, yeoreum(summer) might represent time-related expression with preceding temporal profixes.

\section{Identifying Temporal Expressions and Chunking}

\subsection{Representing Temporal Expression Using FST}

The co-occurrence data extracted by the way described in the previous section can be represented with a finite state machine (Figure 5). For syntactic function disambiguation and chumking, the antomata should produce an output, which leads to a finite state transducer. In fact, individual description for each data could be integrated into one large FST and represented as the right-hand side in Figuro 5. A finite state transducer is defined with a six- 


\begin{tabular}{|c|c|c|}
\hline left context & word & right context \\
\hline 씼고 나중에는 기름에 문힌 & [여름 & 밤]에 물고기들이 물가로 나올 때 \\
\hline 그리고는 소파 위에서 그만 잡이 들었다. & [여름 & 밤]만큼이나 짧았지만 \\
\hline 정권을 빼 앗기고 말았다. 나는 처음에는 & [여름 & 방학] 후에 복학을 하기로 했었고 \\
\hline 새로운 친구들을 빨리 사기게 되었다. & [여름 & 방학] 때에는 부산에 사는 \\
\hline 했다. & [여름 & 방학] 전날 열린 학급 잔치에서 \\
\hline 변화되어야 한다고 완곡하게 설득했다. & [여름 & 빙-학]이 다가오면서 성근이는 여러 \\
\hline 가 같았다. 신학과 3학년 1학기를 마치고 & [여름 & 방학]이 시작된 훙 최종 결심을 했다. \\
\hline 터였다) 봅에 시작된 상아의 생횔문제는 & [여름 & 방학]을 넘기고 가을로 접어들면서 \\
\hline 거부하고 있는 형편이라고 한다. 마침 & [여름 & 방학] 중이라서 시간도 있었고 \\
\hline 이 집은 본래 저씨 부인의 친 & 여름 & 별장]이더니, 그가 별세하메 이 집 \\
\hline 位업, & 여름 & 주말]은 언제나 괴롭다. 매미는 \\
\hline 뇌염 예방 주사를 맞혀 & [여름 & 감기]에 잔기침을 해대거나 콧물을 \\
\hline 되었다. 가게 일 & [여름 & 내내] 피서 한 번 못 가고 가게 일에 \\
\hline 있는지 대학 교수들에게 묻고 싫다. [지난. & 여름] & 나는 10 여 년의 유학에서 놀아와 \\
\hline 그 [해 & & 6.25 전쟁이 터졌다. 학교는 피난민 \\
\hline ! 연이구만!" 그 [해 & & 마지막 늦더위가 기승을 부리는 \\
\hline 요. [이번 & & 가 이긴거죠?" 이긴 \\
\hline
\end{tabular}

Figure 3: Example concordance data of yeoreum(summer)

\begin{tabular}{|c|c|c|c|c|}
\hline before & $\begin{array}{c}\text { temporal noun } \\
\text { yeoreum(summer) }\end{array}$ & after & output & fred \\
\hline & 여름 $/ t_{22}$ & 밚 (bam,night) & $\mathrm{TN}$ & 2 \\
\hline & 여름 $/ t_{22}$ & 빵학(banghag,vacation) & $\mathrm{TN}$ & 7 \\
\hline & 여름/ $/ t_{22}$ & 별장(byeoljang,villa) & $\mathrm{TN}$ & 1. \\
\hline & 여름 $/ t_{22}$ & 주말(jumal,wokends) & $\mathrm{TN}$ & 1. \\
\hline & 여름 $/ t_{22}$ & 감기(gamgi,flu) & $\mathrm{TN}$ & 1 \\
\hline & 여름/ $/ 22$ & 내내/ $t_{26}$ (nacnae, all the timo) & $\mathrm{TA}$ & 1 \\
\hline 지난/t $t_{1}($ jinan, last $)$ & 여름 $/ t_{22}$ & 나는 (naneun,I/TOP $)$ & $\mathrm{TA}$ & 1 \\
\hline 해 $/ t_{10}$ (hac,yoar) & 여름 $/ t_{22}$ & 6.25 , 마지막(majimag,the last) & TA & 2 \\
\hline 이번/ $t_{1}$ (ibcon,this) & 여름 $/ t_{22}$ & 전 투는(jeontune un, battle/TOP) & $\mathrm{TA}$ & 1 \\
\hline
\end{tabular}

Figure 4: Tomporal expression phrases selected from cxamples

tuple $\left(\Sigma_{1}, \Sigma_{2}, Q, i, F, E\right)$ where: $\Sigma_{1}$ is a finite input alphabet; $\Sigma_{2}$ is a finite output, alphabet; $Q$ is a linite set of states or vertices; $i \in Q$ is the initial state; $F \subseteq Q$ is the set of final states; $E \subseteq Q \times \Sigma_{1}^{*} \rightarrow \Sigma_{2}^{*} \times Q$ is the set of transitions or edges.

Although the syntactic function of a temporal oxpression would be nondeterministically selected from the context, temporal expressions and the lexical data of local context can be represented in a deterministic way due to their finite length. For the deterministic FST, we define the partial functions $\otimes$ and $*$ where $q \otimes a=q^{\prime}$ iff $d(q, a)=\left\{q^{\prime}\right\}$ and $q * a=u^{\prime}$ iff $\exists q^{\prime} \in Q$ such that $q \otimes a=q^{\prime}$ and $\delta\left(q, a, q^{\prime}\right)=\left\{w^{\prime}\right\}$ (Roche and Schabes, 1995). Then, a subsequential FST is a eight-tuple $\left(\Sigma_{1}, \Sigma_{2}, Q, i, F, \otimes, *, \rho\right)$ whore: $\Sigma_{1}, \Sigma_{2}, Q, i$ and $F$ are the same as the FST; $\otimes$ is the deterministic state transition function that maps $Q \times \Sigma_{1}$ on $Q ; *$ is the deterministic emission function

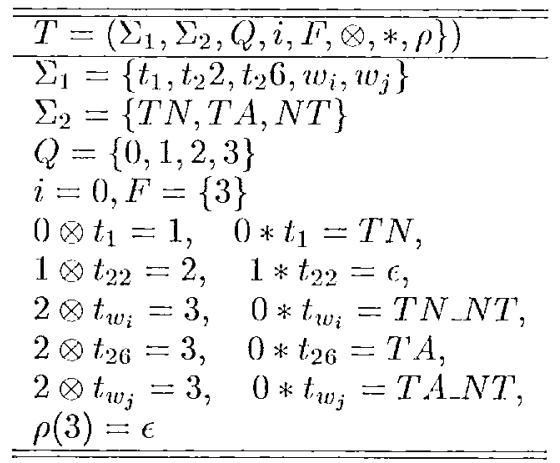

Figure 6: Deterministic FST resulted from Figure 5

that maps $Q \times \Sigma_{1}$ on $\Sigma_{2}^{*} ; \rho: F \rightarrow \Sigma_{2}^{*}$ is the final output function.

Our temporal co-occurrence data can bo represented with a deterministic finite state transducer 

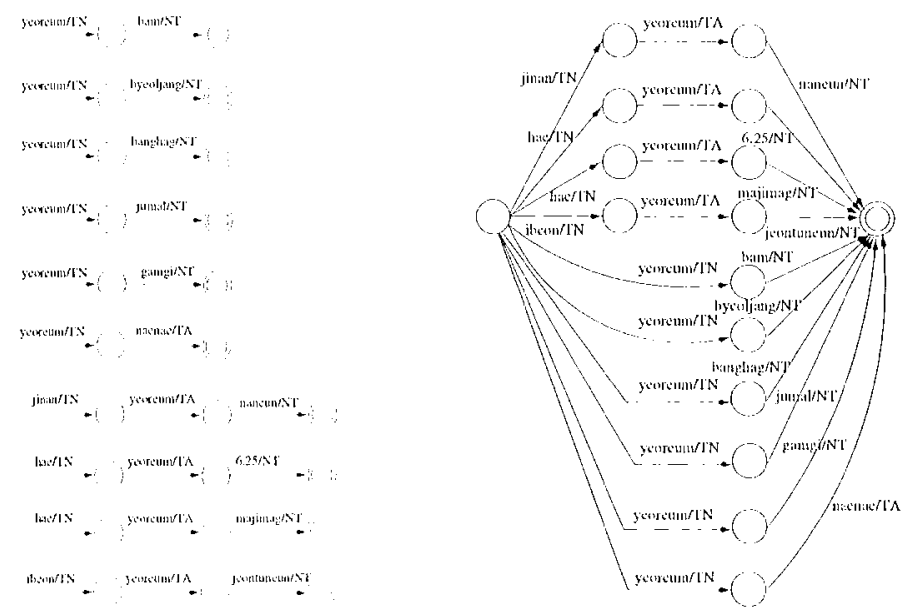

Figure 5: Finite state mathine constructed with the data in Figure 4

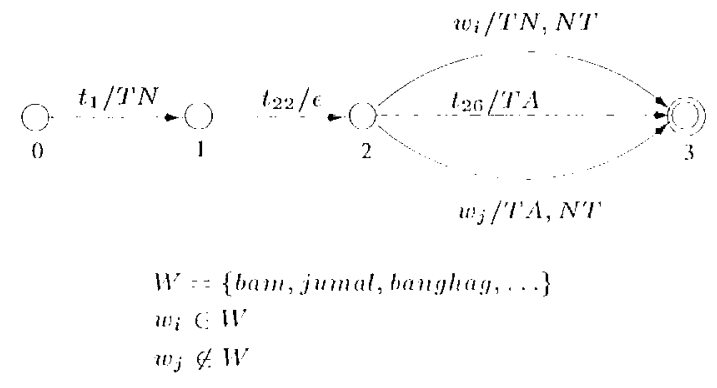

Figure 7: A deterministic finite state transduces to process temporal expression

in a similar: way. 'The subsecuential TSST' for on' system is defined as in Fignee 6 and fighro 7 illustwates the transducer in ligure 6 . In the fighre, $t_{i}$ is a class to which the temporal word bolonges in the temporal elassification. $w_{i}$ is a word other than temporal ones that has the preceding temporal word be its modifier, and $w_{j}$ is not such a word to make a compound noun. $T N, T A$ and $N T$ 'a syntaletic tags. A word tagged with $I$ ' $N$ would nodify a succoeding noum like bam(night), banghag(vacation). A word attached with $T A$ wonld modify a predicate and one with $N T$ means it is not a temporal word. Actually, inclividual FSTS are combined into one and rules for tagging of temporal words are put over the FisT. The rule is applied aceording to the prionity by frequency in case more than one output are possible for a context. Namely, it is a rule-based system where the rules are extracted from corpus.

\subsection{Chunking}

After the FST of temporal expressions adds to words syntactic tags such as $T N$ and $T$, chunking is conducted with results from ontputs by the FST. As we said carlior, chunking in Korean is relativoly casy only if the temporal expression would be sucecess- fully recognized. Actually, our chunkor is also based on the finite state machine. The following is an $\mathrm{cx}-$ ample for chunking rules.

$$
\begin{aligned}
& \left\langle N I^{\prime} h u n k\right\rangle \rightarrow\left\langle N I^{\prime}\right\rangle \mid\left\langle T^{*} I^{\prime}\right\rangle \\
& \left\langle N I^{\prime}\right\rangle \rightarrow\langle N\rangle^{*}\left\langle N I^{\prime}\right\rangle \mid\langle N\rangle^{*}\langle N U\rangle^{*}\langle U N\rangle \\
& \left\langle I^{\prime} I^{\prime}\right\rangle \rightarrow\left\langle I^{\prime} N\right\rangle^{*}\langle N\rangle^{*}\left\langle N I^{\prime}\right\rangle
\end{aligned}
$$

Ilore, $N$ is a noun without any postposition, $N P$ is a noun with a postposition, $T N$ is a temporal nom recognized as modifying a succoding nomn, $N U$ is a number and $U N$ is a unit nom. After temporal tagging, the chunker transforms 'NT' into N, NP', atc. according to morphological constituents and their POS. Briefly, the rule says that an NJ' chunk is made from either NP' or temporal NP. An NP would be constructed with one or nore nomes and their modifice of with a noun clubutified. A TN]', which is related with time, is made from nouns modified by temporal words which would be identijfed by the FST. By identification of tomponal expression and chunking, the following example sentence is chunked as bolow.

- jinan(last) yeoreum(summor) banghag-e(in vacations) uri-neun(wo/SUBJ) keompyuteo(computier) se(three) dae-reul(unit/()]3J) sassda(bought)

$\rightarrow$ Wo bought three computers in the last summer vacation.

- jinan $_{T N}$ yeoream $m_{T N}$ banghag-e $e_{N 1}$ uri-neun $N^{\prime} T^{\prime}$ loompyuteon sco $_{N}$ dac-reul $l_{N}$ sassdaV

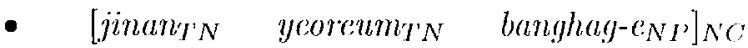
$\left[\text { uri-neun }_{N I}\right]_{N C} \quad\left[\right.$ keompyuteo $N$ se $_{N U}$ dae$\left.\operatorname{reul}_{N P}\right]_{N C}$ sassdar

\section{Experimental Results}

For the experinent about temporal expression, we extracted 300 sentences contatining temporal expressions from LTRI I'OS corpus. 'Table 2 shows the re- 

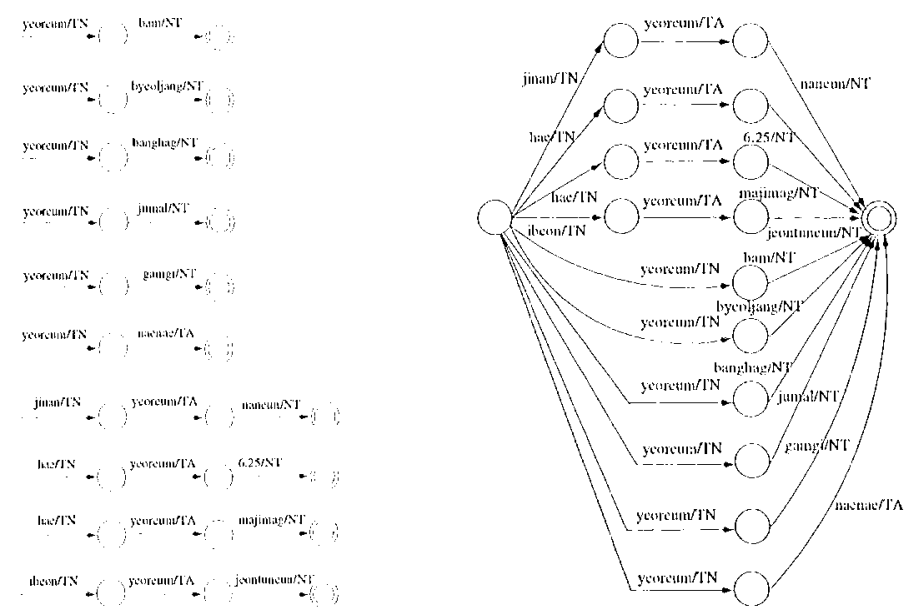

Figure 5: Finite state machine constructed with the data in Figure 4

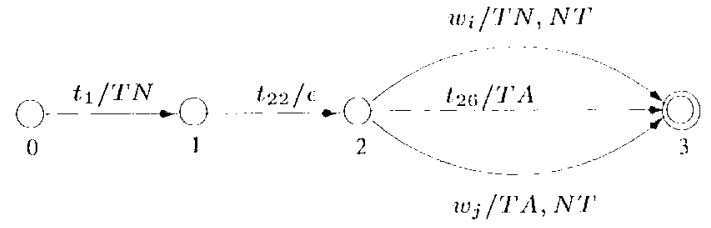

$W=\{$ bam, jumal, ban!gha!g, .. $\}$

$w_{i} \in W$

$w_{j} \notin W$

Figure 7: A deteministic finite state transcheer to process temporal expression

in a similar way. The subsequential FST for our systom is defined as in ligure 6 and Figure 7 illustrates the transducer in Figure 6 . In the figure, $t_{i}$ is a class to which the temporal word belongs in the temporal classification. $w_{i}$ is a word other than temporal ones that has the proceding tenporal word be its modifier, and $w_{j}$ is not such a word to make a compound nown. $T N, T^{\prime} A$ and $N T$ are syntactic tags. A word tagged with $T N$ would modify a succeeding noun like bam(night), banghag(vacention). A word attached with $T A$ would modify a predicate and one with NT' means it is not a temporal word. Actually, individual FST's are combined into one and rules for tagging of temporal words are put over the FST. The rule is applied according to the priority by frequency in case more than one output are possible for a context. Namely, it is a rulo-based system where the rules are extracted from corpus.

\subsection{Chunking}

After the FST of temporal expressions adds to words syntactic tags such as $T N$ and $T A$, chunking is conducted with results from outputs by the FST'. As we said carlier, chnnking in Korean is relatively casy only if the temporal expression wonld be success- fully recognized. Actually, our chunker is also based on the finite state machine. The following is an example for chunking rules.

$$
\begin{aligned}
& \left\langle N I^{\prime} \operatorname{chunk}\right\rangle+\left\langle N I^{\prime}\right\rangle \mid\left\langle T^{\prime} I^{\prime}\right\rangle \\
& \left\langle N{ }^{P}\right\rangle \rightarrow\langle N\rangle^{*}\left\langle N I^{*}\right\rangle \mid\langle N\rangle^{*}\langle N U\rangle^{*}\langle U N\rangle \\
& \left\langle T^{\prime} I^{\prime}\right\rangle \rightarrow\left\langle T^{\prime} N\right\rangle^{*}\langle N\rangle^{*}\left\langle N I^{\prime}\right\rangle
\end{aligned}
$$

Here, $N$ is a nom without any postposition, $N P$ is a noun with a postposition, $T N$ is a temporal nom recognized as modifying a succeoding noun, $N U$ is a numbor and $U N$ is a unit, noun. After temporal tagging, tho chunker transforms 'NT' into N, NP, atc. according to morphological constituents and their POS. Buiefly, the rule says that an NP chunk is made from cither $\mathrm{NP}^{3}$ or timporal $\mathrm{NP}^{3}$. An NP would be constructed with one or more nouns and their modifice or with a noun quentified. A TNP, which is related with timo, is made from nouns modified by temporal words which would be identified by the FST'. By identification of tomporal expression and chunking, the following example sentence is chunked as below.

- jinan(last) yeoreum(summer) banghag-e(in vacation) uri-neun(wo/SUBJ) keompyuteo(computer) se(threo) dae-reul(unit/OBJ) sassda(bought)

$\rightarrow$ We bought the computers in the last summer vacation.

- jinanTN ycoreum ${ }_{T N}$ banghag-e ${ }_{N I}$ uri-ncun ${ }_{N Y}$ keompyuteo $_{N}$ se $_{N}$ dac-reul ${ }_{N}$ sassda

- $\quad\left[\operatorname{jinan}_{T N} \text { yeoream }{ }_{T N} \text { banghag-e }{ }_{N P}\right]_{N C}$ $\left[\text { uri-neun }_{N P}\right]_{N C} \quad\left[k c o m p y u t o_{N} \quad s c_{N U}\right.$ dac$\left.\operatorname{reul}_{N I}\right]_{N O}$ sassdaV

\section{Experimental Results}

For the experimont about temporal expression, wo extracted 300 sentences containing temporal expressions from ETRI POS corpus. Table 2 shows tho ro- 


\begin{tabular}{l|c|c|}
\hline & precision & recall \\
\hline rate (\%) & 97.5 & 90.56 \\
\hline
\end{tabular}

Table 2: Results of identifying temporal expression

\begin{tabular}{|c|c|c|}
\hline & no chunking & using chunking \\
\hline avg. \# of cand & 4.8 & 3.3 \\
\hline
\end{tabular}

Table 3: Reduction of candidates resulted from chunking

sults from identifying temporal expressions and disambiguating their syntactic functions. From the result in the table we see that the method is very effective in that it very accurately identifies all the temporal expressions and assigns them syntactic tags.

And, Table 2 shows the reduction resulted from chunking after tomporal expression identification. Wo take into consideration the average number of heacl candidates for each word since our parser is dependency based ono. The test was conducted on the first file (about 800 sentences) of KAIST treebank (Choi et al. , 1994). The number was reduced by $31 \%$ in candidates compared to the system with no chunking, which makes parsing efficient.

Most of errors were caused by the case where tem poral words have different, syntactic roles under the same context. In this case, the global context such as the whole sentence or intersentential information or sometimes very sophisticated processing is needed to resolve the problem. For instance, '82 nyeon(ycar) hyconjac-yi(now/GEN)' could be used two-way. If the speech time is the year 1982, then hyeonjue-yi are combined with 82 nyeon to represent time. Otherwise, 82 does not modify hyeonjae-yi, which cannot be recognized only with the local context. Nevertheless, the system is promising in that gencrally it can improve efficiency without losing accuracy which is crucial for the practical system.

\section{Conclusions}

In this paper, we presented a method for identification of temporal expressions and their syntactic functions based on FST and lexical data extracted from corpus. Since temporal words have the syntactic ambiguity when used in a sentence, it is important to identify the syntactic function as well as the temporal expression itself.

For the purpose, we manually extracted lexical cooccurrences from large corpus and it was possible as the number of temporal nouns is tractable enough to manipulate lexical data by hand. As shown in the result, lexical co-occurrences are crucial for disambiguating the syntactic function of the tomporal expression. Besides, the finite state approach provided an efficient model for temporal expression pro- cessing. Combined with the chunker, it helped romarkably lessen, by pruning irrelevant candidates, intermediate structures generated while parsing.

\section{References}

Abnoy, S. 1991. Parsing By Chunks. In Berwick, Abncy, and Tenny, editors, Principle-Based Parsing. Boston: Kluwer Academic Publishers.

Choi, K. S., Han, Y. S., Han, Y. G., and Kwon, O. W. 1994. KAIST Tree Bank Project for Korean: Present and Future Development. In Proceedings of the International Workshop on Sharable Natural Language Resources.

Ciravegna, F. and Lavelli, A. 1997. Controlling Bottom-Up Chart Parscrs through Text Chunking. In Proceedings of the 5th International Workshop on Parsing Technology.

Collins, M. J. 1996. A New Statistical Parscr Based on Bigram Lexical Dependencies. In Proceedings of the 34th Annual Mecting of the ACL.

Elgot, C. C. and Mczei, J. E. 1965. On relations defincd by generalized finite automata. IBM Journal of Research and Development, 9, 47-65.

Gross, M. 1993. Local Grammars and their Representation by Finite Automata. Data, Description, Discourse: I'apers on the English language in hornour of John McH Sinclair, Michael Hocy (od). London: HarporCollins Publishers.

KAIST. KAIST Concordance Program. URL htt.tp://csfive.kaist.ac.kr/kcp/.

Mohri, M. 1997. Finite-state Thansducers in language and Speech Processing. Computational Linguistics, Vol $23, \mathrm{No}(2)$.

Ramshaw, L. A. and Marcus, M. I'. 1995. 'Text Chunking Using Transformation-Basod I carning. In Procecdings of the ACL Workshop on Very Large Corpora.

Roche, E. and Schabes, Y. 1995. Deterministic Part-of-Specch Tagging with Finite-State Transduccrs. Computational Linguistics, Vol 21, No (2).

Roche, E. and Schabes, Y. 1997. Finite-State Language Processing. The MTT Press.

Skut, W. and Brants, T. 1999. Chunk Tagger. In Proceedings of ESSLIII-98 Workshop on Automated Acquisition of Syntax and Parsing.

Sproat, R. W., Shih, W., Gale, W. and Chang, N. 1994. A Stochastic Finitc-State Wordsegmentation Algorithm for Chinese. In Proceedings of the 32nd Annual Meeting of ACL

Yoon, J., Choi, K. S. and Song, M. 1999. Three Types of Chunking in Korcan and Dependency Analysis Based on Lexical Association. In Proceedings of ICCPOL' ' 99 . 